\title{
Innovation and Sustainable Tourism: reflections of the state-of-the-art in the period 2010-2017
}

\section{Inovação e Turismo Sustentável: reflexões do estado da arte no período de 2010 a 2017}

\section{Luciana Aparecida Barbieri da Rosa}

PhD student in Management at the Federal University of Santa Maria - UFSM, Santa Maria/RS, Brazil

E-mail: lucianaaparecidabarbieri@yahoo.com.br

\section{Maria Carolina Martins-Rodrigues}

International PhD by the University of Extremadura - UEx/Spain

E-mail: rodriguescarolina@live.com.pt

\section{Luana Ines Damke}

PhD student in Management at the Federal University of Santa Maria - UFSM, Santa Maria/RS, Brazil

E-mail: luanadamke@hotmail.com

\section{Tais Pentiado Godoy}

PhD student in Management at the Federal University of Santa - UFSM, Santa Maria/RS, Brazil

E-mail: taispentiado@yahoo.com.br

\section{Clandia Maffini Gomes}

PhD professor at the Federal University of Santa Maria - UFSM, Santa Maria/RS, Brazil E-mail: clandia@smail.ufsm.br

Article received on: 03-23-2019

Article approved on: 11-12-2019 


\section{ABSTRACT}

This article aims to launch the publications on Innovation and Sustainable Tourism, part of the research in the Web of Science database of ISI Web of Knowledge. Thus, the objective of this article is to analyse as characteristics of the publications related to the theme Innovation and Sustainable Tourism in the period from 2010 to 2017, totalling 199 selected articles. The methodology used for this study, is a bibliometric and descriptive research. The survey results show the year with the highest number of publications was 2016 (44). Journal of Sustainable Tourism presented the highest number of publications with a total of 20 .

Keywords: Bibliometry. Innovation. Sustainable Tourism.

\section{RESUMO}

Este artigo tem como propósito apresentar o cenário das publicações sobre Inovação, Gestão Estratégica e Turismo Sustentável, partindo da pesquisa na base de dados Web of Science da ISI Web of Knowledg. Dessa forma, o objetivo deste artigo é analisar as características das publicações relacionadas com o tema Gestão Estratégica e Turismo Sustentável no período de 2010 a 2017, totalizando 199 artigos selecionados. A metodologia utilizada foi uma pesquisa bibliométrica, descritiva. Os resultados da pesquisa mostram que o ano de maior número de publicações foi 2016 (44). Journal of Sustainable Tourism apresentou o maior número de publicações com o total de 20.

Palavras-chave: Bibliometria. Inovação. Turismo Sustentável. 


\section{INTRODUCTION}

Innovation and sustainability are being studied and worked in the most diverse activities, sectors or spheres. In order to succeed in any kind of business or enterprise, you must know how to innovate and be attentive to what society has been looking for, and today it is known that most people want quality, innovative products that do not bring bigger damage to the environment.

Every day, countries, regions and emerging organizations are performing better by instituting innovative management practices as their main competitive weapon, which have the opportunity to obtain differentials in quality, cost, flexibility, and reliability.

According to Gollo (2006), these organizations are changing the way they run their business, understanding that there is a new dynamic in the globalized world and one of the ways to gain competitive advantage is to be proactive to changes in real time, beating market expectations, developing emerging innovations in products, processes, and services, adopting strategic and management models that meet their needs and those of their stakeholders. In today's globalized business world, companies need to know how to cooperate with some stakeholders and compete with others by participating in a network of competitive and cooperative relationships within the institutional environment (Bengtsson \& Kock, 2000).

Irrespective of the area of operation, whether industrial, commercial or services, organizations need to be innovative and show concern for sustainability to stay in the market, especially with regard to social and environmental dimensions, otherwise they will be forgotten or exchanged by some competitor who fulfills those requirements, since the modern consumer has been concerned about the environment and the society of which he is a part.

Concern about the issue of sustainability arose from various discussions, which became more relevant from 1972 at the Stockholm Conference. In addition, Agenda 21 brings together 113 countries and, according to Meller (1997), represents a milestone for the emergence of environmental movements. From then on, sustainable development is discussed almost daily, and in the most diverse areas, including tourism, object of study in this work.

Sustainable tourism must be one that safeguards the environment and natural resources, ensuring the economic growth of the activity, that is, able to meet the needs of present and future generations. Therefore, tourism development should be guided by "saving rare and precious natural resources, especially water and energy, and avoiding, whenever possible, the production of waste (Article 3 Code of Ethics - WTO). 
The Sustainable Tourism should above all seek to reconcile the desires of tourists and the receiving regions, not only ensuring the protection of the environment, but also stimulating the development of the activity in line with the local community involved.

Develop tourism in a sustainable way implies actions that are socially just, economically viable and environmentally friendly, that is, that meet the needs economic, social and ecological society. Therefore, to enter this new wave of sustainable tourism, companies that work with it must know how to innovate and bring a differential that attracts attention and captivates their customers.

In fact, tourism, because of its economic, social and cultural importance, is an important pillar for the economy and development of many regions, since it carries with it a number of very relevant activities, so that regional and local governments interested in promoting the local and regional development see tourism as a strong partner in the search for such development. On the other hand, planning has "played a more important role in tourism development as governments have come to recognize not only that the sector generates a broad spectrum of impacts but also that it can play an important role in social and economic growth and revitalization. cultural "(World Trade Organization - WTO, 2003, p. 215).

In this way, if tourism is considered one of the most important agents of change in any society, then it can not fail to evolve without planning. However, this planning should be strategic, inclusive, participatory and pluralistic in order to address the social, economic and environmental dimensions (Gunn, 1994). This means that there are various types of tourism planning and that their application will depend on the reality of each country, region or locality, ie location, tourism market, specific resources and policies adopted (Inskeep, 1991).

The present study, in addition to this introduction, is organized in five sections, the review of the literature presented explaining the different concepts of innovation and sustainable tourism, later the methodology of the study, analysis and discussion of the results and finally the final considerations of this research.

\section{REVIEW OF LITERATURE}

\subsection{Innovation: different concepts}

Due to business competitiveness, the need to innovate is a goal to achieve a competitive differential market. Elements such as technological, scientific growth and the development of the media, mean that competition among companies is increasing. In this 
way, it's necessary to create new processes, products, and services so that the company can stay in the market.

According to the authors, Bessant and Tidd (2009), the innovation is basically centered on three main factors: the creation of new ideas, selection of the best and implementation. For Schumpeter (1934), innovation was considered essential for economic growth, which is increasingly a key factor in a competitive advantage for organizations of products and services. The first works focused on the specificities of the innovation process, result in analyses of the diffusion of technological innovation from the industry.

Innovation is essential to question the fitness room is companies to the business world and even for the world economy, it is necessary to have innovation capacity. For Çakar and Ertük (2010), it is one of the most important dynamics that enables small and medium organizations to seek competitiveness, both in national and international markets. According to Schumpeter (1997), innovation is defined as a discontinuous process of what is established by the standards, thus arising new combinations from the production of things by different methods or even new things.

Innovation is considered one of the basic activities that contribute to survival (Greve, 2003), and to the profitability and growth of organizations (Roberts, 1999). It is noteworthy that literature reviews have explored, competition strategies, or research on innovation (Bengtsson \& Raza-Ullah; Bengtsson, Raza-Ullah, \& Vanyushyn, 2016) explored the relationship of competition strategies and research on innovation (Park, Srivastava, \& Gnyawali, 2014), yet there are still gaps to enhance the development of two themes innovation and competitiveness - which are new research and opportunity in this direction.

According to Vianna, Vianna, Adler, Lucena and Russo (2012), innovation consists of reanalyzing business patterns that do not exist or exist in the market, that attend the needs of the consumers. In this way, it can also be explained as the marketing of services, processes, products, methods of business practices, which are original or even improved, according to the Oslo Manual (Organisation for Economic Cooperation and Development - OECD, 2005).

According to researchers, innovation is considered as an essential element in competitive advantage (Dess \& Picken, 2000), and also as a determining motive in organizational performance (Mone, Mckinley, \& Barker, 1998). Thus, increasing the size of the market, creating new products, are the major challenges faced by organizations, which can be addressed through incremental or radical innovations (Belderbos, Carree, \& Lokshin, 2004), where innovation can happen through the systemic interaction of educational 
institutions, universities and companies, and can be planned and implemented by the government (Lundvall, 2007; Dewes \& Padula, 2012).

Authors such as Gnyawali and Park (2011), describe that one way to promote innovation is through competition, which is increasingly common in the organizational environment, such as the outcome of the product lifecycle and the rising costs of R \& D. With respect to another field, it is noticed that the interchange among the competitors is a way to multiply the learning resources and results, through interactivity, within a network of organizations (Dolińska, 2015).

\subsection{Sustainable tourism: different views}

In the last decade, the studies on the tourism theme have been studied on the different optics and areas of knowledge. In this perspective, the state of the art and the concepts that define tourism are numerous and it is important to highlight the concern with the development of tourism, as it operates in various sectors such as social, economic, cultural and environmental.

Rodrigues (2000) defines tourism as: "A complex activity that includes both production and consumption, both the secondary (space production) and tertiary (service) activities that act articulately appropriating" exotic "places," natural landscapes "," historical landscapes " transforming them into places that should be observed in order to obtain cultural, historical knowledge, to enable rest, and several other symbolic or real motives (Rodrigues, 2000, p. 48).

Sustainable tourism was explicitly defined at the Tamanrasset Conference in 1989, respecting not only the tourist practice itself, attributable to the visitor but also passing through the production, the varied set of infrastructure that underlies and allows the existence of visitors in a certain place.

In the words of Seabra (2001, p. 29) sustainable tourism is "the form of harmonious leisure, based on self-determination, valuing native populations and respecting the environment." Already Swarbrooke (2000, p. 19) defines -o as "tourism that is economically viable, but that does not destroy the resources on which the future depends on tourism, especially the physical environment and the social fabric of the local community".

However, it consolidated - in the last decade as a fundamental part of the studies on the management of tourism resources. However, the desired sustainable development of tourism has - become the target of numerous rhetorical conceptions and most often do not materialize in planning efficient policies. (Sánchez \& Fernández, 2008). 
In addition, Rodrigues (2000, p. 44), mentions that: "Consider sustainable tourism or member of the possibility of sustainable development is only divert the terms of the question without analyzing the complexity of economic activity that is based on the consumption of exotic natural landscapes or past history".

In this context, for Jacobi (2006, p. 115) sustainable tourism returns to the concept of sustainability, which: "It implies a necessary interrelationship between social justice, quality of life, environmental balance and the need for development. This represents the possibility of ensuring sociopolitical changes that do not compromise the ecological and social systems on which communities are based".

Sustainable Tourism is a way of maintaining actions for the preservation of the environment, seeking to meet local needs and tourists, without neglecting the regional culture, biological diversity and ecological systems that coordinate life (Medeiros \& Moraes, 2013).

Still, Silva (2004) highlights an essential point regarding the aforementioned theme in the previous paragraphs. The author emphasizes that there is a diversified existence of specificities of sustainable tourism, where these studies depart more from theories than investigations empirically. Thus, it is essential that future researchers seek to transform these theoretical discussions into ratifications based on empirical essays that are focused on the sustainability tripod and based on repeated or deferred findings since the theory must be linked to practice.

\section{METHODOLOGY}

This work is a bibliometric study. As for type it is a quantitative and descriptive work. For operational purposes we use the articles that were published between the years 2010 and 2017 on the theme Innovation and Sustainable Tourism.

The data were collected directly from the Web of Science database (WOS) from the Institute for Scientific Information (ISI), one of the largest multidisciplinary databases that encompass data, abstracts and citations from the scientific literature. In the field of research was inserted the words Innovation and Sustainable Tourism, so, they identified the main writers on the subject, among other features, and investigated articles published $\mathrm{n}$ the period under review, in order to present the context in which you ma is referenced. This information has been arranged in Excel tables for your analysis. 


\subsection{Definition of the study scope}

The research of the publications to perform bibliometrics was made from the search engines of the WOS database. This database holds roughly one third journals indexed, and only, the most cited in their respective areas, such as Journal of Sustainable Tourism, Tourism Management, Sustainability, Journal of Cleaner Production, Tourism in South East Europe. At WOS there is a citation index, where it is mentioned for each article, the documents cited by it and the documents that quoted it (Figure 1).

Figure 1 - Distribution of articles by type of publication

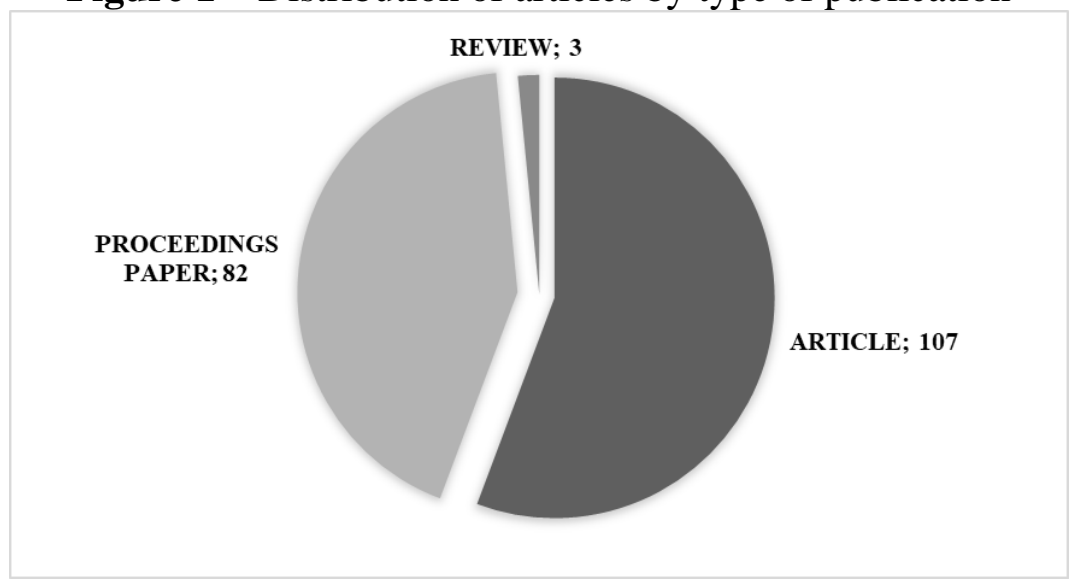

Source: Prepared by the author, 2017.

Bibliometrics aims to evaluate the scientific or technical activity of a given area of knowledge through the quantitative study of publications (Silva, 2004; Leite Filho, 2008). Rousseau (2001) and Camps, Samar, Ávila and Recuero (2006) define bibliometrics as a discipline that allows the quantitative study of scientific production, through the analysis of its own nature and the transfer of a science in a given period.

Bibliometrics is a set of research methods that employ quantitative and statistical analyzes to map knowledge in a given scientific field (Vanti, 2002). Thus, bibliometric studies of scientific production are governed by Lotka's Law, Bradford's Law and Zipf's Law (Table 1).

Chueke and Amatucci (2015) report that the Lotka Law aims to increase or impact an author's production in a knowledge area; The Bradford Law aims to identify the most relevant and leaky journals, and the purpose of the Zipf Law is to estimate the most recurring topics related to a field of knowledge.

The terms Innovation and Sustainable Tourism were searched in the Web of Science in the period between 2010 and 2017, resulting in a total of 199, being 107 articles, 82 proceedings. 
In the bibliometric analysis of the present study we tried to identify the following variables: main authors, title of the sources, main institutions, year of publications, main countries and languages, areas of knowledge and the relationship between authors with more publications and those most cited

\subsection{Steps of data collection}

This study was divided into two stages; placed or herself the terms Innovation and Sustainable Tourism, in the search field of the WOS base, delimiting the period from 2010 to 2017. Then he proceeded to the survey of the general characteristics of the publications. In the second stage, the most cited publications were compared with the authors who published the most in the same period.

Figure 2 - Research steps

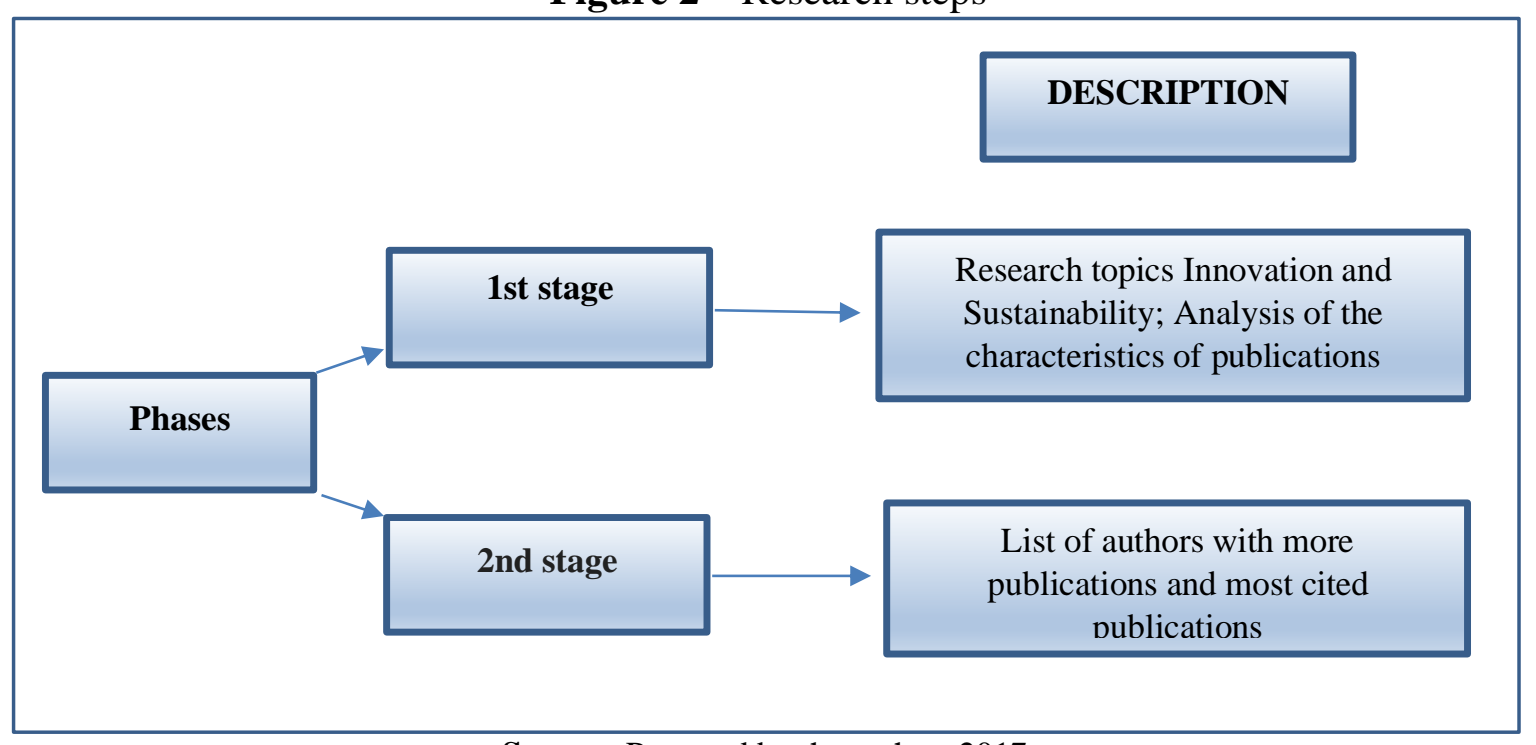

Source: Prepared by the author, 2017.

Therefore, according to the steps described in Figure 2, the bibliometric analysis of the aforementioned study was performed, as shown below.

\section{RESULTS AND DISCUSSION}

The results of the study presented below to identify the main features of scientific production in the Web of Science database relational them with keywords Innovation and Sustainable Tourism in the period 2010 to 2017. After refining the search for categories of Innovation and Sustainable Tourism still, to choose to present results referring to articles and conferences, a total of 199 articles were obtained. The general characteristics of the 
publications will be presented: the main authors, the title of the sources, main institutions, year of publications, main countries, and languages and research areas. Then, the number of publications per author and the number of citations will be displayed.

\subsection{General characteristics of the publications on innovation and sustainable tourism: in Web Of Science}

The general characteristics of publications related to the themes Innovation and Sustainable Tourism are presented below. in the categories of main authors, a title of sources, institutions, year of publications, countries, languages and research areas.

\subsubsection{Main authors}

Figure 3 presents the top ten authors who published articles with the themes Innovation and Sustainable Tourism in the analyzed period.

Figure 3 - Distribution of articles by authors

\begin{tabular}{|l|c|}
\hline Authors & Quantity article \\
\hline Cismaru, L. & 4 \\
\hline Bratucu, G. & 3 \\
\hline Della-Gala, M. & 2 \\
\hline Dinan, C. & 2 \\
\hline Dinca, G. & 2 \\
\hline Erkus-Ozturk, H. & 2 \\
\hline Felicetti, A.M. & 2 \\
\hline Horng, J.S. & 2 \\
\hline Liu, C.H. & 2 \\
\hline Lozano, J. & 2 \\
\hline Mazilu, M. & 2 \\
\hline
\end{tabular}

Source: Prepared by the author, 2017.

It has been found to be a multiplicity and diversity as to the authorship of the work involving the analyzed topics. Two authors $m$ stands themselves with four (4) and 3 (three) articles published in the period under review, and the other authors published two articles in the same period. Thus, there is the absence $\mathrm{d}$ and an investigator who stand out when analyzing the themes of Innovation and Sustainable Tourism simultaneously. 


\subsubsection{Title of sources}

Figure 4 shows the main sources of publications and a number of published articles related to the theme of Innovation and Sustainable Tourism.

Figure 4 - Distribution of articles by source

\begin{tabular}{|l|c|c|}
\hline \multicolumn{1}{|c|}{ Sources of Publications } & $\begin{array}{c}\text { Number of } \\
\text { articles }\end{array}$ & $\%$ \\
\hline Journal of Sustainable Tourism & 20 & $10,05 \%$ \\
\hline Tourism Management & 8 & $4,02 \%$ \\
\hline Sustainability & 7 & $3,52 \%$ \\
\hline Journal of Cleaner Production & 5 & $2,51 \%$ \\
\hline Tourism in South East Europe & 5 & $2,51 \%$ \\
\hline IFKAD 2014 9Th International Forum on Knowledge Asset Dynamics & 4 & $2,01 \%$ \\
\hline International Journal of Contemporary Hospitality Management & 4 & $2,01 \%$ \\
\hline International Multidisciplinary Scientific Conferences Social Sciences Arts & 4 & $2,01 \%$ \\
\hline Journal of Environmental Protection and Ecology & 4 & $2,01 \%$ \\
\hline Kybernetes & 4 & $2,01 \%$ \\
\hline
\end{tabular}

Source: Prepared by the author, 2017.

The journal that published the most was Journal of Sustainable Tourism.

\subsubsection{Main institutions}

In Figure 5 They have presented the ten institutions that stood out and published works related to the theme of Innovation and Sustainable Tourism.

Figure 5 - Distribution of articles by main institutions

\begin{tabular}{|l|c|}
\hline \multicolumn{1}{|c|}{ Institutions } & Quantity article \\
\hline Griffith University & 5 \\
\hline Hong Kong Polytechnic University & 4 \\
\hline Tianjing University of Finance Economics & 4 \\
\hline Transylvania University of Brasov & 4 \\
\hline University of Johannesburg & 4 \\
\hline University of Naples Federico II & 4 \\
\hline Akdeniz University & 3 \\
\hline Sun Yat Sen University & 3 \\
\hline Universitat de Les Illes Balears & 3 \\
\hline University of Basilicata & 3 \\
\hline
\end{tabular}

Source: Prepared by the author, 2017.

It can be seen that the institutions that published the most were: Griffith University in Australia, Hong Kong Polytechnic University in Hong Kong, Tianjin University of Finance Economics in China, Transylvania University of Brasov in Romania, University of 
Johannesburg in Johannesburg. The data presented above show the scope and importance of the theme in educational institutions around the world.

\subsubsection{Annually published articles}

Figure 6 shows the number of Web of Science articles related to the theme Innovation and Sustainable Tourism, they were published between 2010 and 2017.

Figure 6 - Distribution of articles per year

\begin{tabular}{|c|c|c|}
\hline Years & Quantity article & \% \\
\hline 2016 & 56 & $28,14 \%$ \\
\hline 2015 & 40 & $20,10 \%$ \\
\hline 2013 & 27 & $13,57 \%$ \\
\hline 2014 & 27 & $13,57 \%$ \\
\hline 2017 & 23 & $11,56 \%$ \\
\hline 2010 & 9 & $4,52 \%$ \\
\hline 2012 & 9 & $4,52 \%$ \\
\hline 2011 & 8 & $4,02 \%$ \\
\hline Total..... & 199 & $100,00 \%$ \\
\hline
\end{tabular}

Source: Prepared by the author, 2017.

From 2014 the scientific production related to the theme increased, evidencing the highest growth in 2015, because this year is the year that seventeen sustainable development goals were defined, as set out at the UN summit in New York, and growth the interest by the investigators.

\subsubsection{Main countries}

The number of articles distributed by the main countries is shown in Figure 7.

Figure 7 - Distribution of articles by country

\begin{tabular}{|l|c|c|}
\hline Countries & Quantity article & \% \\
\hline China & 34 & $17,09 \%$ \\
\hline Italy & 26 & $13,07 \%$ \\
\hline Spain & 17 & $8,54 \%$ \\
\hline England & 14 & $7,04 \%$ \\
\hline Australia & 11 & $5,53 \%$ \\
\hline Taiwan & 9 & $4,52 \%$ \\
\hline Germany & 8 & $4,02 \%$ \\
\hline Romania & 8 & $4,02 \%$ \\
\hline USA & 8 & $4,02 \%$ \\
\hline France & 7 & $3,52 \%$ \\
\hline
\end{tabular}

Source: Prepared by the author, 2017. 
It was found that the most publications focused on countries such as People's Republic of China, Italy, Spain, England, Australia. It is highlighted that in the twenty-second place we have Portugal with two articles published in the Web of Science on the theme Innovation and Sustainable Tourism, which reveals that this theme is still little worked.

\subsubsection{Main languages}

As for the languages of the works published in the study area, they are published in English, as shown in Figure 8, corresponding to $93,97 \%$ the works.

Figure 8 - Distribution of articles by language

\begin{tabular}{|l|c|c|}
\hline Languages & Quantity article & $\%$ \\
\hline English & 187 & $93,97 \%$ \\
\hline Spanish & 5 & $2,51 \%$ \\
\hline Chinese & 4 & $2,01 \%$ \\
\hline Slovak & 2 & $1,01 \%$ \\
\hline
\end{tabular}

Source: Prepared by the author, 2017.

\subsubsection{Research areas}

The areas of research with the largest number of publications were Social Sciences other topics, Business Economics, Environmental Sciences Ecology, according to Table 1.

Table 1 - Distribution of articles by research areas

\begin{tabular}{|l|c|c|}
\hline Research Areas & Quantity article & $\%$ \\
\hline Social Sciences other Topics & 95 & $47,74 \%$ \\
\hline Business Economics & 56 & $28,14 \%$ \\
\hline Environmental Sciences Ecology & 42 & $21,11 \%$ \\
\hline Science Technology other Topics & 36 & $18,09 \%$ \\
\hline Engineering & 12 & $6,03 \%$ \\
\hline Education Educational Research & 10 & $5,03 \%$ \\
\hline Computer Science & 8 & $4,02 \%$ \\
\hline Geography & 6 & $3,02 \%$ \\
\hline Public Administration & 6 & $3,02 \%$ \\
\hline Urban Studies & 5 & $2,51 \%$ \\
\hline
\end{tabular}

Source: Prepared by the author, 2017.

Total articles in the list are 276. It is seen that the total of articles is higher than the number of publications (199), it is not surprising that an article is linked to more than one area. 


\subsubsection{Most cited articles from 2010 to 2017}

In the period from 2010 to 2017 were identified 607 citations. The Table 2 shows the twelve (12) most cited articles on Innovation and Sustainable Tourism held in the database Web of Science.

Table 2 - List of the twelve most cited publications in the period (2010-2017)

\begin{tabular}{|c|c|c|c|c|}
\hline $\begin{array}{l}\text { Number of } \\
\text { Quotations } \\
2010-2017\end{array}$ & Title & Author & Journal & Year \\
\hline 83 & $\begin{array}{l}\text { Environmental governance for } \\
\text { sustainable tourism development: } \\
\text { Collaborative networks and } \\
\text { organization building in the } \\
\text { Antalya tourism region }\end{array}$ & $\begin{array}{l}\text { Erkus-Ozturk, Hilal; } \\
\text { Eraydin, Ayda }\end{array}$ & $\begin{array}{c}\text { Tourism } \\
\text { Management }\end{array}$ & 2010 \\
\hline 49 & $\begin{array}{l}\text { Entrepreneurship and Innovation } \\
\text { at the Base of the Pyramid: A } \\
\text { Recipe for Inclusive Growth or } \\
\text { Social Exclusion? }\end{array}$ & $\begin{array}{l}\text { Hall, Jeremy; Matos, } \\
\text { Stelvia; Sheehan, } \\
\text { Lorn; } \quad \text { Silvestre, } \\
\text { Bruno }\end{array}$ & $\begin{array}{l}\text { Journal of } \\
\text { Management } \\
\text { Studies }\end{array}$ & 2012 \\
\hline 44 & $\begin{array}{l}\text { Towards innovation } \\
\text { sustainable tourism research? }\end{array}$ & $\begin{array}{l}\text { Bramwell, } \\
\text { Lane, Bernard }\end{array}$ & $\begin{array}{l}\text { Journal of } \\
\text { Sustainable } \\
\text { Tourism }\end{array}$ & 2012 \\
\hline 40 & $\begin{array}{l}\text { Tourism governance and } \\
\text { sustainable national development } \\
\text { in China: a macro-level synthesis }\end{array}$ & $\begin{array}{l}\text { Sofield, Trevor; Li, } \\
\text { Sarah }\end{array}$ & $\begin{array}{c}\text { Journal of } \\
\text { Sustainable } \\
\text { Tourism }\end{array}$ & \\
\hline 34 & $\begin{array}{l}\text { The diffusion of environmental } \\
\text { sustainability innovations in } \\
\text { North American hotels and ski } \\
\text { resorts }\end{array}$ & $\begin{array}{l}\text { Smerecnik, Karl R.; } \\
\text { Andersen, Peter A }\end{array}$ & $\begin{array}{l}\text { Journal of } \\
\text { Sustainable } \\
\text { Tourism }\end{array}$ & 2011 \\
\hline 29 & $\begin{array}{l}\text { Building dynamic capabilities } \\
\text { through knowledge resources. }\end{array}$ & $\begin{array}{l}\text { Nieves, Julia; Haller, } \\
\text { Sabine }\end{array}$ & $\begin{array}{c}\text { Tourism } \\
\text { Management }\end{array}$ & 2014 \\
\hline 26 & $\begin{array}{l}\text { Knowledge networks in the } \\
\text { tourism sector of the } \\
\text { Bournemouth, Poole, and } \\
\text { Christchurch conurbation: } \\
\text { preliminary analysis. }\end{array}$ & $\begin{array}{lr}\text { McLeod, Michelle } \\
\text { Theresa; Vaughan, } \\
\text { David Roger; } \\
\text { Edwards, Jonathan }\end{array}$ & $\begin{array}{l}\text { Service Industries } \\
\text { Journal }\end{array}$ & 2010 \\
\hline 20 & $\begin{array}{l}\text { Normative and innovative } \\
\text { sustainable resource management } \\
\text { at birding festivals }\end{array}$ & $\begin{array}{l}\text { Lawton, Laura Jane; } \\
\text { Weaver, } \quad \text { David } \\
\text { Bruce }\end{array}$ & $\begin{array}{l}\text { Tourism } \\
\text { Management }\end{array}$ & 2010 \\
\hline 19 & $\begin{array}{l}\text { Customer Involvement in } \\
\text { Sustainable Supply Chain } \\
\text { Management: A Research } \\
\text { Framework and Implications in } \\
\text { Tourism }\end{array}$ & Sigala, Marianna & $\begin{array}{l}\text { Cornell Hospitality } \\
\text { Quarterly }\end{array}$ & 2014 \\
\hline 18 & 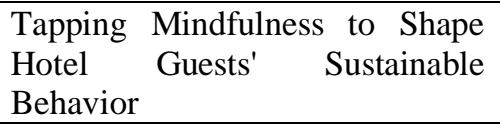 & $\begin{array}{l}\text { Barber, Nelson A.; } \\
\text { Deale, Cynthia }\end{array}$ & $\begin{array}{l}\text { Cornell Hospitality } \\
\text { Quarterly }\end{array}$ & 2014 \\
\hline 14 & $\begin{array}{l}\text { Using indicators to assess } \\
\text { sustainable tourism development: } \\
\text { a review }\end{array}$ & $\begin{array}{l}\text { Torres-Delgado, } \\
\text { Anna; Saarinen, } \\
\text { Jarkko }\end{array}$ & $\begin{array}{l}\text { Tourism } \\
\text { Geographies }\end{array}$ & 2014 \\
\hline 12 & 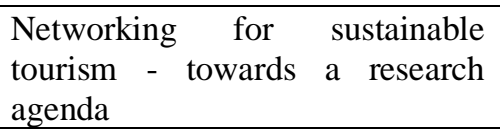 & Albrecht, Julia N. & $\begin{array}{c}\text { Journal of } \\
\text { Sustainable } \\
\text { Tourism }\end{array}$ & 2013 \\
\hline
\end{tabular}

Source: Prepared by the author, 2017. 
Comparing Table 2 with Figure 3, it was found that the author Hilal Erkus-Ozturk list of the ten that published on the subject in the period between 2010 and 2017, was the most cited with 83 of 12 (twelve) authors most cited in the Web of Science at that time.

\section{CONCLUSIONS}

The goal des you study aimed to check what features of the national scientific production and international relating $\mathrm{m}$ the Innovation and Sustainable Tourism issues. To accomplish the objective of the study, a bibliometric study was carried out using the Web of Science database, whose final sample resulted in the analysis of 199 articles.

As for the research perspectives, it shows that the interests and foci of research on the theme Innovation and Sustainable Tourism are growing for scientific knowledge. With this, it was possible to map and analyse the scientific production scenario related to the theme of Innovation and Sustainable Tourism. The subject was considered interdisciplinary because the articles are related to more than one area of knowledge.

In relation to the dissemination vehicle, it was verified that the Journal of Sustainable Tourism presented the largest number of publications (20), followed by Tourism Management (8) and Sustainability (7)

The publications focused on countries such as the People's Republic of China, Italy, and Spain. Portugal occupies the twenty-second position of the 25 countries that published the most on the subject and Brazil is not included in it.

From 2014 the scientific production related to the theme increased, evidencing the highest growth in 2015, because this year coincides with the year will go down as the year that seventeen sustainable development goals were defined, as set out at the UN summit in New York, which brought together world leaders intent on adopting an agenda with a view to the eradication of poverty and for economic, social and environmental development on a global scale by 2030, which became known as 2030, the Agenda for Sustainable Development.

As for the authors who published the most in this theme, there was a multiplicity and diversity regarding the authorship of the works. It was found that only one of Dec authors who have published on the subject appears in the list of 12 (twelve) most cited authors: Hilal Ozturk Erkus-2 publications and 83 quotations). The most prominent institutions in publications related to Innovation and Sustainable Tourism were: Griffith University ( Australia), Hong Kong Polytechnic University ( Hong Kong), Tianjing University of Finance Economics (China), Transylvania University of Brasov (Romania), University of 
Johannesburg (Johannesburg), University of Naples Federico II (Italy), Akdeniz University (Turkey), Sun Yat-sen University (China), Universitat de les Illes Balears (Mallorca), University of Basilicata (Italy).

The contribution of this article to the studies in Management is due to the resulting indicators regarding the research institutions and the newspapers that stand out most in the production of the knowledge on the subject at international level.

The present study found the following limitations: 1) the main limitation of this study refers to the fact that only the search term "Innovation and Sustainable Tourism" was used; 2) because the information presented is limited to articles selected only in the Web of Science database; 3) limitation bibliometric analysis limited to authors, articles, sources, institutions, countries, language and period.

For future studies, it is suggested to expand research on the theme of Innovation and Sustainable Tourism, other databases and national and international scientific events, in order to compare results; to undertake other bibliometric analyzes, such as the formation of networks of authors and institutions; to carry out a systemic analysis with the aim of analyzing other content different from those analyzed in the present study, such as: which theories have been worked together and in which countries and perform the bibliometric analysis of the abstracts and references of the selected articles.

There were no Portuguese or Brazilian researchers in the list of the most published authors on the subject, which reinforces the idea that this theme needs to be further studied in these two countries and in the future may be a research tool for dissertations and doctoral theses with this one theme.

\section{REFERENCES}

Belderbos, R., Carree, M., \& Lokshin, B. (2004). Cooperative R\&D and firm performance. Research Policy, 33(10), 1477-1492.

Bengtsson, M., \& Kock, S. (2000). Coopetition in business networks - to cooperate and compete simultaneously. Industrial Marketing Management, 29, 411-426.

Bengtsson, M., \& Raza-Ullah, T. (2016). A systematic review of research on coopetition: Toward a multilevel understanding. Industrial Marketing Management, 57, 23-39.

Bengtsson, M., Raza-Ullah, T., \& Vanyushyn, V. (2016). The coopetition paradox and tension: The moderating role of coopetition capability. Industrial Marketing Management, 53, 19-30.

Bessant, J., \& Tidd J. (2009). Inovação e empreendedorismo. Porto Alegre: Bookman. 
Çakar, N. D., \& Ertürk, A. (2010). Comparing innovation capability of small and mediumsized enterprises: examining the effects of organizational culture and empowerment. Journal of Small Business Management, 48(3), 325-359.

Camps, D., Samar, M. E., Ávila, R. E., \& Recuero Y. (2006). Estudio bibliométrico de un volumen de la revista Archivos de Medicina. Arch Med., 2(3).

Chueke, G. V., \& Amatucci, M. (2015). O que é bibliometria? Uma introdução ao fórum. Internext, 10(2), 1-5.

Dess, G. G., \& Picken, J. C. (2000). Changing roles: Leadership in the 21 st century. Organizational dynamics, 28(3), 18-34.

Dewes, M. F., \& Padula, A. D. (2012). Inovação em um programa estratégico de desenvolvimento: o Programa Espacial Brasileiro. Revista Brasileira de Inovação, 11(1).

Dolińska, M. (2015). Knowledge based development of innovative companies within the framework of innovation networks. Innovation, 17(3), 323-340.

Gnyawali, D. R., \& Park, B. J. R. (2011). Co-opetition between giants: Collaboration with competitors for technological innovation. Research Policy, 40(5), 650-663.

Gollo, S. S. (2006). Delineamento e aplicação de framework para análise das inovações numa perspectiva de processo interativo: estudo de caso da indicação de procedência Vale dos Vinhedos - Serra Gaúcha/RS. Teoria e Evidência Econômica, 14, 247-277.

Greve, H. R. (2003). A behavioral theory of R\&D expenditures and innovations: Evidence from shipbuilding. Academy of Management Journal, 46(6), 685-702.

Gunn, C. (1994). Emergence of effective tourism planning and development. In: Seaton, A. (Ed.). Tourism: the state of the art. Chichester: Wiley.

Inskeep, E. (1991). Tourism planning: an integrated and sustainable development Approach. New York: Van Nostrand Reinhold.

Jacobi, P. (2006). Gestão compartilhada de resíduos sólidos no Brasil: inovação com inclusão social. São Paulo: Annablume.

Leite Filho, G. A. (2008). Padrões de produtividade de autores em periódicos e congressos na área de contabilidade no Brasil: um estudo bibliométrico. Revista de Administração Contemporânea, Curitiba, 12(2), 533-554.

Lundvall, B. A. (2007). National innovation systems - analytical concept and development tool. Industry and innovation, 14(1), 95-119.

Medeiros, L. C., \& Moraes, P. E. S. (2013). Turismo e Sustentabilidade Ambiental: referências para o desenvolvimento de um turismo sustentável. Revista Meio Ambiente e Sustentabilidade, 3(2).

Meller, C.B. (1997). A educação ambiental como possibilidade para superação da fragmentação do trabalho escolar. Dissertação de Mestrado em Educação nas Ciências, 
Universidade Regional do Noroeste do Estado do Rio Grande do Sul - UNIJUÍ, Ijuí, RS, Brasil.

Mone, M. A., McKinley, W., \& Barker, V. L. (1998). Organizational decline and innovation: A contingency framework. Academy of Management Review, 23(1), 115-132.

Organização para Cooperação Económica e Desenvolvimento - OCDE. (2005). Manual de Oslo: diretrizes para coleta e interpretação de dados sobre inovação. (3a. Ed.). Rio de Janeiro: FINEP.

Park, B. J., Srivastava, M. K., \& Gnyawali, D. R. (2014). Impact of Coopetition in the aliance portfolio and coopetition experience on firm innovation. Technology Analysis \& Strategic Management, 26(8), 893-907.

Roberts, P. W. (1999). Product innovation, product-market competition and persistent profitability in the US pharmaceutical industry. Strategic management journal, 20(7), 655670 .

Rodrigues, A. M. A. (2000). Desenvolvimento sustentável e atividade turística. In: Serrano, C., Bruhns, T. H., \& Luchiari, M. T. D. P. (Org.). Olhares contemporâneos sobre o turismo. Campinas: Papirus.

Rousseau R. (2001). Indicadores bibliométricos y econométricos en la evaluación de instituciones científicas. ACIMED, 9, 23-9.

Sánchez, M. R., \& Fernández, J. I. P. (2008). Medida de la sostenibilidad turística: propuesta de un índice sintético basado en ponderaciones factoriales. Anais da IX Convocatória Premio Tribuna Fitur Jorge Vila Fradera 2007, Madrid, Espanha.

Schumpeter, J. (1934). The theory of economic development. Cambridge: Harvard University Press.

Schumpeter, J. A. (1997). Teoria do desenvolvimento económico. São Paulo: Editora Nova Cultural Ltda.

Seabra, G. F. (2001). Ecos do turismo: o turismo ecológico em áreas protegidas. Campinas: Papirus.

Silva, C. (2004). As possibilidades e impossibilidades da sustentabilidade do sistema turístico. Anais do Encontro Nacional de Turismo com base local da Universidade Federal do Paraná, Curitiba, PR, Brasil.

Silva, M. R. (2004). Análise bibliométrica da produção científica docente do programa de pós-graduação em educação especial/UFSCar. Dissertação de Mestrado em Educação Especial, Universidade Federal de São Carlos, São Carlos, SP, Brasil.

Swarbrooke, J. (2000). Turismo sustentável: turismo cultural, ecoturismo e ética. (5a. Ed.). São Paulo: Aleph.

Vanti, N. A. P. (2002). Da bibliometria à webometria: uma exploração conceitual dos mecanismos utilizados para medir o registro da informação e a difusão do conhecimento. Ciência da Informação, 31(2), 152-162. 
Vianna, M., Vianna, Y., Adler I., Lucena B., \& Russo, B. (2012). Design Thinking: Inovação em negócios. Rio de Janeiro: Mjv Press.

World Trade Organization. (2003). Turismo internacional: uma perspectiva global. (2a. Ed.) São Paulo: Bookman.

\section{FORMAT FOR CITATION OF THIS ARTICLE}

ROSA, L. A. B., MARTINS-RODRIGUES, M. C., DAMKE, L. I., GODOY, T. P., \& GOMES, C. M. (2020). Innovation and Sustainable Tourism: reflections of the state-of-the-art in the period 2010-2017. Revista de Turismo Contemporâneo, 8(1), 88-106.

https://doi.org/10.21680/2357-8211.2020v8n1ID17192 